\title{
NEWS FROM THE DEPARTMENTS
}

University of Alberta. Mr. A.J. Keeping has been appointed Assistant Professor of Mathematics. He is a Cambridge M.A., with the Diploma in Numerical Analysis, and is assisting Dr. D. B. Scott and Dr. J. McNamee in the work of the University Computing Centre.

The I. B. M. 1620 computor has been installed and is functioning well.

Professor R.H. Bing, from the University of Wisconsin, visited both the Calgary and Edmonton campuses in October, as a Visiting Lecture $r$ of the Mathematical Association of America.

Seminars on Algebraic Number Theory (Chwe), Lattice Theory (Lowig) and Advanced Differential Equations (Sinclair) a re being given.

University of British Columbia. Dr. Roy Westwick has been appointed to an Assistant Professorship as of July 1, 1962.

Seminars:

Multi-Linear Functions and Tensors - Marcus

Analysis

- Sion

Ha rmonic Analysis

- Clark, Sion, Swanson

Algebraic Geometry

- Ono, Chu, Kobayashi

This Fall a series of Saturday morning lectures has been offered by the Departments of Mathematics and English to a selected group of some two hundred high school students. The purpose of the scheme was to acquaint prospective university students with the University and with the subjects involved.

Professors James, Jennings, Divinsky, Benedicty, Hull and Christian spoke for the Mathematics Department.

The series will be continued into second term and Professors Moyls, Simons, and Marcus will be some of the speakers. 


\section{Members: \\ University of Manitoba. Summer 1961 Activities of Staff}

Professor N. Mendelsohn participated in an Algebra Seminar at U.C. L.A. Professor L. Dulmage participated in a Combinatorial Symposium at RAND Corporation in Santa Monica. Professor B. Noonan attended the Kingston Research Institute. Professor W. Moser taught a 6 week N.S.F. Summer Institute for High School teachers of Mathematics at Central Michigan University.

Professor W. Moser has been appointed Editor-in-chief of the Canadian Mathematical BuIletin.

Mr. H. Finlayson is on leave of absence and is studying at the University of Minnesota towa rds the Ph. D.

Dr. J. Swirles, who was on staff 1958-60, rejoined the staff as Assistant Professor.

Mr. R. Dowling, from the College of St. Thomas (St. Paul), joined the staff as Assistant Professor.

L'Université de Montréal. M. Anatole Joffe a été nommé assistant-professeur à compter du ler septembre. Il était professeur I'an dernier à I' Université McGill.

Le Dr. Charles Krueger de I'Université d'Illinois a été nommé attaché de recherche à compter du ler septembre. Le Dr. Heinrich Kleisli qui était l'an demier attaché de recherche a été nommé cet automne assistant professeur à I'Université d'Ottawa.

Le Dr. Waclaw Zawadowski, après un séjour d'un an et demi à titre d'attaché de recherche, est retourné en Pologne, à I' Université de Varsovie.

Le professeur Alexis Zinger est en congé d'études pour une année à I'Université d'Oxford. Le Dr. Zinger est boursier du Conseil National de Recherches.

M. André Barbeau a obtenu un doctorat en mathématiques en juin dernier. M. Barbeau a effectué ses recherches sous la direction du professeur Gabriel Thierrin. On trouvera un résumé de sa thèse dans le présent numéro du Bulletin. 
Queen's University. The number of students enrolled for Post Graduate degrees in Mathematics rose from 7 in the 1960-61 session to 16 in the present session. Of these, four a re candidates for the Ph. D. The number of students in Mathematics 10, rose from 80 in 1960-61 to 130 currently. Mathematics 10 is the first Course taken by students who hope to do Honours in mathematics or a related field.

The following are new appointments as Assistant Professors in the session 1961-62:

Donald Bures - Bures took his Ph. D. at Princeton under Professor W. Feller with a thesis entitled "THE TYPE OF CERTAIN FACTORS CONSTRUCTED AS INFINITE TENSOR PRODUCTS";

George Bush - Bush took his Ph. D. at Queen's University under Professor I. Halperin with a the sis entitled "ON IMBEDDING A SEMIGROUP IN A GROUP";

Uri Fixman - Fixman took his Ph. D. at the Hebrew University, Jerusalem, under Professor A. Dvoretzky with a thesis entitled "PROBLEMS ON SPECTRAL OPERATORS".

Professor H. W. Ellis has been appointed Secretary of the MathematicaI Research Institute of the Congress.

University of Saskatchewan. A seminar for teachers of high school mathematics was held at the University of Saskatchewan from July 17 to August 12, 1961 with Dr. G. H. M. Thomas as director. A limited number of copies of a report of this seminar are available to those who a re interested.

Dr. Kuo-Tsai Chen of the Instituto Techologico de Aeronautica, São Jose dos Campos, Brazil has been appointed associate professor of mathematics, effective July 1, 1962.

Dr. Ronald Butler of the College of Science and Technology, Manchester, England has been appointed visiting associate professor of mathematics.

The University of Saskatchewan announces the retirement of Professor H.H. Ferns as head of the department of mathematics, effective June 30,1962. Professor A.P. Guinand has been appointed head of the department of mathematics effective July 1, 1962. 